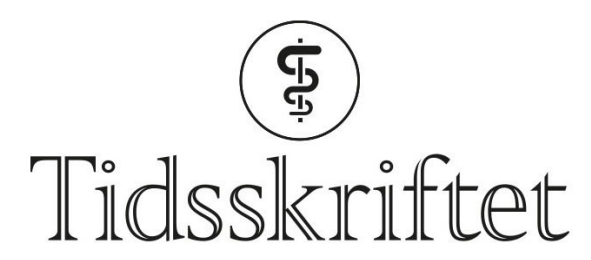

DEN NORSKE LEGEFORENING

\title{
Inflammasjonsdempende medisin etter hjerteinfarkt?
}

FRA ANDRE TIDSSKRIFTER

TORBJØRN ØYGARD SKODVIN

Tidsskriftet

Behandling med kolkisin etter hjerteinfarkt var forbundet med mindre angina pectoris og færre hjerneslag, men ikke med færre dødsfall.

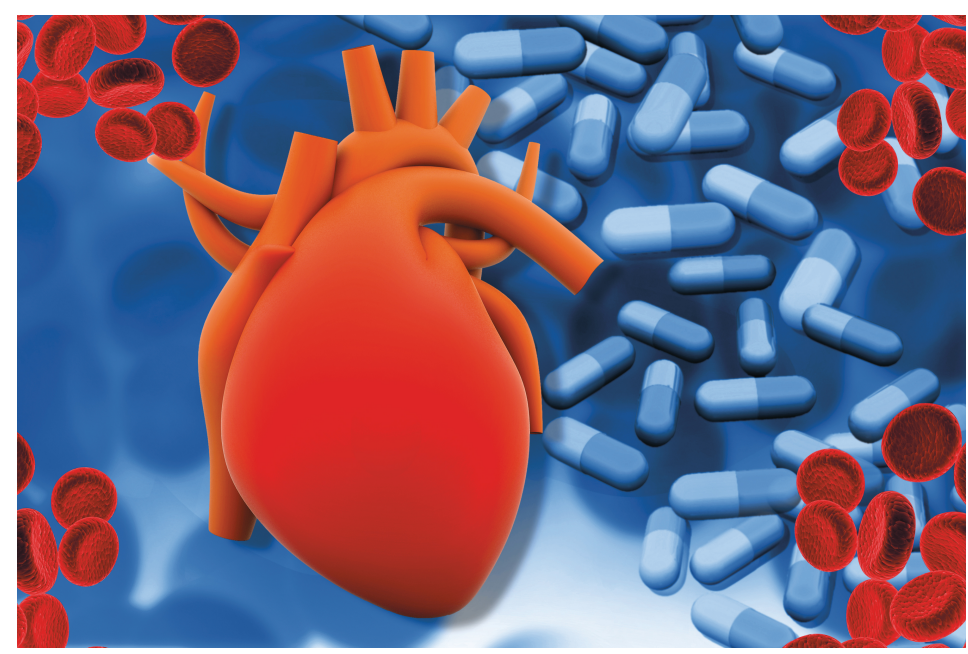

Illustrasjon: bluebay2014/iStock

Inflammasjon spiller sannsynligvis en viktig rolle i utvikling av aterosklerose og akutte iskemiske hendelser.

I en randomisert multisenterstudie med nesten 5 ooo hjerteinfarktpasienter fra tolv land fikk rundt halvparten en lav dose av det inflammasjonsdempende middelet kolkisin daglig, mens den andre halvparten fikk placebo (1). I løpet av de neste to årene ble 5,5\% av pasientene i kolkisingruppen rammet av ny kardiovaskulær hendelse eller $\mathrm{d} ø \mathrm{~d}$, sammenliknet med 7,1 \% i placebogruppen, dvs. en hasardratio på o,84 (95\% KI o,61-0,96). Forskjellen var størst for angina pectoris og hjerneslag. Lungebetennelse oppsto noe hyppigere i kolkisingruppen enn i placebogruppen, men ellers var det ingen forskjeller hva gjaldt alvorlige bivirkninger.

- Denne studien viser at inflammasjonsdempende medisiner har et potensial i etterkant av hjerteinfarkt, sier Pål Aukrust, som er professor ved Universitetet i Oslo og seksjonsleder ved Seksjon for klinisk immunologi og infeksjonssykdommer ved Oslo universitetssykehus. Behandlingen må ifølge Aukrust rettes mot de riktige molekylene, ettersom andre studier 
har vist effekt ved behandling mot interleukin-1 $\beta$, men ingen effekt av metotreksat når det gjelder kardiovaskulære hendelser hos pasienter med stabil aterosklerotisk sykdom.

LITTERATUR:

1. Tardif J-C, Kouz S, Waters DD et al. Efficacy and safety of low-dose colchicine after myocardial infarction. N Engl J Med 2019;381: 2497-505. [PubMed][CrossRef]

Publisert: 27. mars 2020. Tidsskr Nor Legeforen. DOI: 10.4045/tidsskr.20.0096

(C) Tidsskrift for Den norske legeforening 2020. Lastet ned fra tidsskriftet.no 